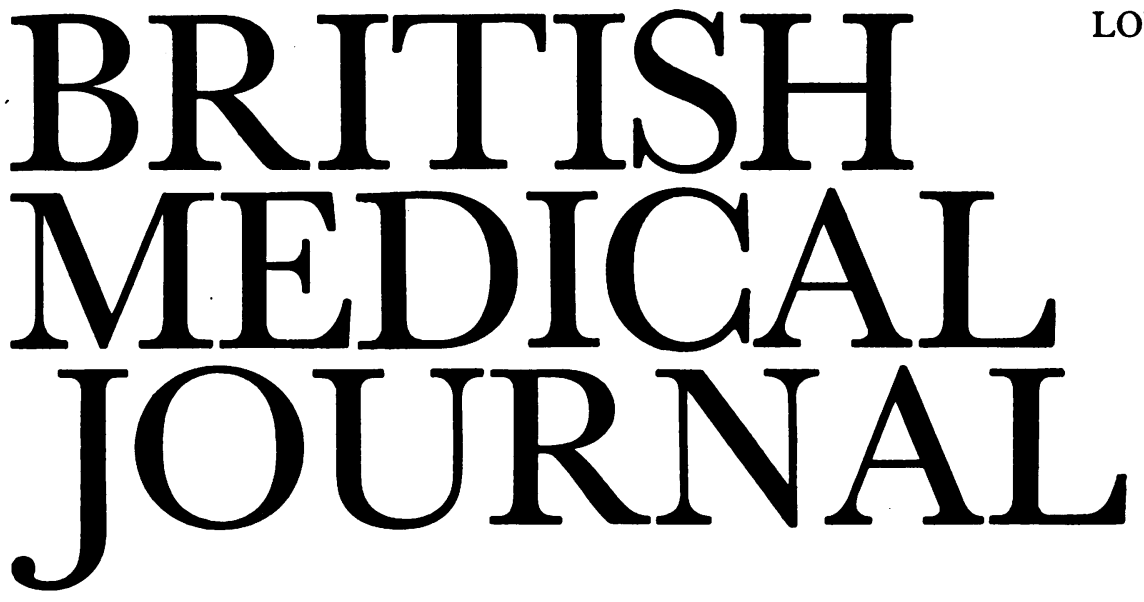

LONDON, SATURDAY 21 NOVEMBER 1987

\title{
Caffeine and health
}

"Caffeine is probably the world's most popular drug." In coffee, tea, cola drinks, cocoa, chocolate, and sometimes proprietary medicines, it is taken regularly by most of the population from childhood onwards. Given its wide consumption, the health hazards are few, but caffeine has been attacked for a statistical association with various diseases. Many of these ghosts have now been banished: fears of a causative role in urinary tract ${ }^{2-4}$ and pancreatic cancer, ${ }^{5-7}$ teratogenesis, ${ }^{89}$ spontaneous abortion, ${ }^{10}$ and fibrocystic breast disease ${ }^{11} 12$ have largely been dispelled. ${ }^{13-33}$

The relation of caffeine to ischaemic heart disease is harder to resolve. A large Norwegian study showed a strong, independent, positive relation between coffee consumption and serum total cholesterol and triglyceride concentrations. ${ }^{34}$ Evidence from other countries, however, is conflicting. ${ }^{35-41}$ Discrepancies may partly depend on the methods of preparation: Norwegians traditionally boil coffee (100-500 mg caffeine/cup) while other Europeans and Americans drink percolated (100-150 mg caffeine/cup), drip brewed (100$120 \mathrm{mg}$ ), or instant coffee (80-100 mg). ${ }^{1}$ Intervention studies suggest that boiled but not filtered coffee raises the serum cholesterol concentration, ${ }^{42} 43$ possibly by reducing bile secretion, which might account for the lowered incidence of colonic cancer in coffee drinkers. ${ }^{44}$

As for myocardial infarction the evidence is insufficient to incriminate caffeine, ${ }^{4546}$ despite both positive ${ }^{47}$ and negative findings. ${ }^{18} 48$ Caffeine may promote arrhythmias, precipitating acute events in established coronary arterial disease. ${ }^{47} 4950$ A recent prospective study, however, found no relation between coffee consumption and any major cause of death. ${ }^{18}$ Thus caffeine, except perhaps at very high levels of intake, appears blameless as a risk to bodily health.

Attention now centres on caffeine's psychotropic and addictive properties, and its effects on psychological health. Caffeine is a central nervous system stimulant, mainly producing this effect by adenosine receptor antagonism..$^{5152}$ It may interact weakly with benzodiazepine receptors ${ }^{53}$ and release $\beta$ endorphin, ${ }^{54}$ and it stimulates noradrenaline release in non-tolerant subjects. ${ }^{55}$ In moderate doses (200$300 \mathrm{mg}$ ) caffeine can elevate mood, improve psychomotor and intellectual performance, and increase electroencephalographic arousal. ${ }^{51}$ 57-59 Larger doses are anxiogenic, producing symptoms indistinguishable from anxiety neurosis ${ }^{60}$ includ- ing insomnia, headache, irritability, tremor, nausea, and diarrhoea. ${ }^{5160}$ Sensitivity to these effects varies among individuals, depending on tolerance, ${ }^{56}$ rate of absorption, and metabolism ${ }^{61}{ }^{62}$ (the half life of caffeine is doubled by oral contraceptives and increased in pregnancy ${ }^{45}$ ) and with age $e^{45}$ and adverse personality ${ }^{61}$ and psychological factors. ${ }^{63}$

In heavy chronic users (12-15 cups of coffee/day), "caffeine has the cardinal features of a prototypic drug of abuse."64 Double blind studies in which the dosage was manipulated showed that caffeine may be reinforcing in man and can produce tolerance and physical dependence with an abstinence syndrome of dysphoria, headache, lethargy, irritability, poor concentration, and anxiety. ${ }^{6465}$

In the general population heavy caffeine consumers report more somatic and psychological symptoms than light users. ${ }^{66}$ Among students caffeine intake correlates positively with the neuroticism score, ${ }^{67}$ and students with high intakes have psychosomatic symptoms and relatively poor academic performance. ${ }^{68}$ Children are not immune from the behavioural effects of caffeine, ${ }^{69}$ and some consume surprisingly large amounts. ${ }^{46}$ In patients with psychiatric illness a high caffeine consumption is associated with more psychological and somatic symptoms. ${ }^{70}$ Patients with panic disorders are particularly sensitive to the anxiogenic effects of caffeine, ${ }^{6371}$ which may also exacerbate schizophrenic and manic-depressive symptoms. ${ }^{72-74}$ Caffeine antagonises benzodiazepines, ${ }^{75}$ and coffee and tea (though not caffeine) substantially interfere with the absorption of phenothiazines. ${ }^{76}$ Such interactions may confuse diagnosis and treatment in psychiatry. ${ }^{77}$

Whether the symptoms of ill health associated with heavy caffeine consumption are the cause or effect of the intake is not clear, nor are the implications for most moderate caffeine users. Many advocate prudence (below $600 \mathrm{mg}$ caffeine daily), especially for those with ischaemic heart disease, hypercholesterolaemia, anxiety and psychiatric disorders, and in pregnancy..$^{456678}$ Although one cannot be complacent about the chronic use of psychotropic drugs, caffeine in moderation appears benign compared with alcohol or smoking as a drug of addiction or a health hazard.

Finally there is more to tea and coffee than caffeine: they contain hundreds of substances. ${ }^{45}$ Decaffeinated coffee has greater gastrointestinal effects than caffeine, ${ }^{45}$ and instant 
coffee, decaffeinated or plain, contains a potent naloxone like opiate. $^{54}$

C H Ashton

Reader in Psychopharmacology,

University Department of Pharmacological Sciences,

The Medical School,

Newcastle upon Tyne NE2 4HH

1 New South Wales Centre for Education and Information on Drugs Alcohol. Information sheet: caffeine. Sydney, NSW: CELDA, 1983.

2 Cole P. Coffee drinking and cancer of the lower urinary tract. Lancet 1971;1:1335-7.

3 Shennan DH. Renal carcinoma and coffee consumption in 16 countries. Br $\mathcal{J}$ Cancer 1973;28: 473-4.

4 Schmauz R, Cole P. Epidemiology of cancer of the renal pelvis and ureter. $\mathcal{f}$ Natl Cancer Inst 1974;52:1431-4.

5 MacMahon B, Yen S, Trichopoulos D, Warren K, Nardi G. Coffee and cancer of the pancreas. N Engl F Med 1981;304:630-3.

6 Clavel F, Benhamon E, Tarayre M, Flamant R. More on coffee and pancreatic cancer. $N$ Englf Med 1987;316:483-4.

7 Hsieh C-C, MacMahon B, Yen S. More on coffee and pancreatic cancer. N Engl J Med 1987;316:484.

8 Weathersbee PS, Olsen LK, Lodge JR. Caffeine and pregnancy: a retrospective survey. Postgrad Med 1977;62:64-9.

9 Jacobson MF, Goldman AS, Syme RH. Coffee and birth defects. Lancet 1981;i:1415-6.

10 Scrisuphau WPH, Bracken MB. Caffeine consumption during pregnancy and association with late spontaneous abortion. Am $\mathcal{F}$ Obstet Gynecol 1986;154:14-20.

11 Boyle CA, Berkowitz GS, Livolsi VA, et al. Caffeine consumption and fibrocystic breast disease: a case-control epidemiological study. $\mathcal{F}$ Natl Cancer Inst 1984;72:1015-9.

12 Minton JP, Abou-Issa H, Reiches N, Roseman JM. Clinical and biochemical studies on methylxanthine-related fibrocystic brain disease. Surgery 1981;90:299-304.

13 Nomura A, Heilbrun LK, Stemmerman GN. Prospective study of coffee consumption and the risk of cancer. I Natl Cancer Inst 1986;76:587-90.

14 Yu MC, Mack TM, Hanisch R, Cicioni C, Henderson ME. Cigarette smoking, obesity, diuretic use, and coffee consumption as risk factors for renal cell carcinoma. I Natl Cancer Inst 1986;77:351-6.

15 Wynder EL, Mabuchi K, Whitmore WF. Epidemiology of cancer of the kidney. $\mathcal{F}$ Natl Cancer Inst 1974;53:1619-34.

16 McLaughlin JK, Mandel JS, Blot WJ, Schuman LM, Mehl ES, Fraumeni JF. A population based case control study of renal cancer. F Natl Cancer Inst 1984;72:275-84.

17 Armstrong B, Garrod A, Doll R. A retrospective study of renal cancer with special reference to coffee and animal protein consumption. Br J Cancer 1976;33:127-36.

18 Jacobson BK, Bjelke E, Kvale G, Hench I. Coffee drinking, mortality, and cancer incidence: results from a Norwegian prospective study. I Natl Cancer Inst 1986;76:823-31.

19 Linn S, Schoenbaum SC, Monson RR, Rosner B, Stubblefield PG, Ryan KJ. No association between coffee consumption and adverse outcomes of pregnancy. N Engl $\mathcal{J}$ Med 1982;306: 141-5.

20 Rosenberg L, Mitchell AA, Shapiro S, Slone D. Selected birth defects in relation to caffeinecontaining beverages. $\mathscr{F A M A}$ 1982;247:1429-32.

21 Kurpa K, Holmberg PC, Kuesma E, Saxen L. Coffee consumption during pregnancy. $N$ Englf Med 1982;306:1548.

22 Feinstein AR, Horwitz RI, Spitzer WO, Battista RN. Coffee and pancreatic cancer: the problem of etiologic science and epidemiological case-control research. JAMA 1981;246:957-61.

23 Shedlofsky S. Coffee and cancer of the pancreas. $N$ Engl I Med 1981;304:1604.

24 Chalmers TC. Coffee and cancer of the pancreas. N Engl I Med 1981;304:1605.

25 Higgins I, Stolley P, Wynder EL. Coffee and cancer of the pancreas. $N$ Engl $\mathcal{J ~ M e d}$ 1981;304:1605.

26 Hsieh C-C, MacMahon B, Yen S, Trichopoulos D, Warren K, Nardi G. Coffee and pancreatic cancer. N Engl $\}$ Med 1986;315:587-9.

27 Severson RK, Davis S, Polissar L. Smoking, coffee and cancer of the pancreas. $\mathrm{Br} \mathrm{Med} \mathrm{J}$ 1982;285:214.

28 Nomura A, Heilbrun LK, Stemmermann GN. Coffee and pancreatic cancer. Lancet 1984;i:917.

29 Kinlen L, Goldblatt P, Fox J, Yudkin J. Coffee and pancreas cancer: controversy in part explained? Lancet 1984; ;:282-3.

30 Ernster VL, Mason L, Goodson WH, et al. Effects of caffeine-free diet on benign breast disease: a randomised trial. Surgery 1982;91:263-7.

31 Lubin F, Ron E, Wax Y, Black M, Funaro M, Shitrit A. A case-control study of caffeine and methylxanthines in benign breast disease. JAMA 1985;253:2388-92.

32 Leviton A. Epidemiological studies of birth defects. In: Dews PB, ed. Caffeine: perspectives from recent research. Berlin: Springer, 1984:188-200.

33 Grice HC. The carcinogenic potential of caffeine. In: Dews PB, ed. Caffeine: perspectives from recent research. Berlin: Springer, 1984:201-20.

34 Thelle DS, Arnesen E, Førde OH. The Troms $ø$ heart study. N Engl f Med 1983;308:1454-7.

35 Dawber TR, Kannel WB, Gordon T. Coffee and cardiovascular disease: observations from the Framingham study. N Engl $f$ Med 1975;291:871-4.

36 Hofman A, Laar A van, Klein F, Valkenburg HA. Coffee and cholesterol. N Engl f Med 1983;309:1248-9.

37 Kovar MG, Fulwood R, Feinleib M. Coffee and cholesterol. N Engl Y Med 1983;309:1249.

38 Shekelle RB, Gale M, Paul O, Stamler J. Coffee and cholesterol. N Engl I Med 1983;309:1249-50.

39 Arab L, Kohlmeier M, Schlierf G, Schettler G. Coffee and cholesterol. N Engl f Med 1983;309:1250.

40 Shirlow M, Mathers C. Coffee and cholesterol. N Engl J Med 1983;309:1250.

41 Williams PT, Wood PD, Vranizan KM, Albers JJ, Garay SC, Taylor CB. Coffee intake and elevated cholesterol and apolipoprotein B levels in man. fAMA 1985;253:1407-11.

42 Arnesen T, Førde OH, Thelle DS. Coffee and serum cholesterol. Br Med $\mathcal{f}$ 1984;288:1960.

43 Førde OH, Knutsen SF, Arnesen E, Thelle DS. The Troms $ø$ heart study: coffee consumption and serum lipid concentrations in man with hypercholesterolaemia: a randomised intervention study. Br Med F 1985:290:893-5.

44 Jacobson BK, Thele DS. Coffee, cholesterol, and colon cancer: is there a link? Br Med $\mathcal{F}$ 1987;294:4-5.

45 Curatolo PW, Robertson D. The health consequences of caffeine. Ann Intern Med 1983;98:641-53.

46 Abbott PJ. Caffeine: a toxicological overview. Med J Aust 1986;145:518-21.

47 LaCroix AZ, Mead LA, Liang K-L, Thomas CB, Pearson TA. Coffee consumption and the incidence of coronary heart disease. $N$ Engl $\mathcal{F}$ Med 1986;315:977-82.
48 Yano K, Reed DM, MacLean C. Coffee consumption and the incidence of coronary heart disease. N Engl f Med 1987;316:946.

49 Graboys TB, Lown B. Coffee, arrhythmias and common sense. N Engl I Med 1983;308:835-7. 50 Dobmeyer DJ, Stine RA, Leier CV, Greenberg R, Schaad SF. The arrhythmogenic effects of caffeine in human beings. N Engl F Med 1983;308:814-6.

51 Rall TW. Central nervous stimulants. In: Gilman AG, Goodman LD, Gilman A, eds. The pharmacological basis of therapeutics. New York: Macmillan, 1980:592-607.

52 Snyder SH. Adenosine receptors and the actions of methylxanthines. Trends in Neuroscience 1981;4:242-4.

53 Boulenger J-P, Patel J, Marangos PJ. Effects of caffeine and theophylline on adenosine and benzodiazepine receptors in human brain. Neurosci Lett 1982;30:161-6.

54 Boublik JH, Quinn MJ, Clements JA, Herington AC, Wynne KN, Funder JW. Coffee contain potent opiate receptor binding activity. Nature 1983;301:246-8.

55 Robertson D, Frohlich JC, Carr RK, et al. Effects of caffeine on plasma renin activity, catecholamines and blood pressure. N Engl f Med 1978;298:181-6.

56 Robertson D, Hollister AS, Kincaid D, et al. Caffeine and hypertension. Am $\mathcal{J}$ Med 1984;77: $54-60$.

57 Lader M, Bruce M. States of anxiety and their induction by drugs. $\mathrm{Br} \mathcal{f}$ Clin Pharmacol 1986;22:251-61.

58 Pollock VE, Teasdale T, Stern J, Volavka J. Effects of caffeine on resting EEG and response to wave-modulated light. Electroencephalogr Clin Neurophysiol 1981;51:470-6.

59 Ashton H, Millman JE, Telford R, Thompson JW. The effects of caffeine, nitrazepam and cigarette smoking on the contingent negative variation in man. Electroencephalogr Clin Neurophysiol 1974;37:59-71.

60 Greden JF. Anxiety or caffeinism: a diagnostic dilemma. Am J Psychiatry 1974;131:1089-92.

61 Sawyer DA, Julie HL, Turin AC. Caffeine and human behaviour: arousal, anxiety, and performance effects. I Behov Med 1982;5:415-39.

62 Goldstein A, Warren R, Kaiser S. Psychotropic effects of caffeine in man. I. Individual differences in sensitivity to caffeine-induced wakefulness. $\mathcal{J}$ Pharmacol Exp Ther 1965;149:156-9.

63 Boulenger J-P, Uhde TW, Wolff A, Post RM. Increased sensitivity to caffeine in patients with panic disorders. Arch Gen Psychiatry 1984;41:1067-71.

64 Griffiths RR, Bigelow GE, Liebson IA. Human coffee drinking: reinforcing and physical dependence producing effects of caffeine. I Pharmacol Exp Ther 1986;239:416-25.

65 Griffiths RR, Woodson PP. Reinforcing properties of caffeine: studies in humans and laboratory animals. Pharmacol Biochem Behav (in press).

66 James JE, Crosbie J. Somatic and psychological health implications of heavy caffeine use. $\mathrm{Br} \mathcal{J}$ Addict 1987;82:503-9.

67 Golding JF, Cornish AM. Personality and life-style in medical students: psychopharmacological aspects. Psychology and Health (in press).

68 Gilliland $\mathrm{K}$, Andress D. Ad lib coffee consumption, symptoms of caffeinism and academic performance. Am I Psychiatry 1981;138:512-4.

69 Rapoport JL, Berg CJ, Ismond DR, Zahn P, Neims A. Behavioural effects of caffeine in children. Arch Gen Psychiatry 1984;41:1073-9.

70 Bezchlibnyk KZ, Jeffries JJ. Should psychiatric patients drink coffee? Canad Med Ass $\mathcal{f}$ 1981;124:357-8.

71 Lee MA, Cameron OG, Greden JF. Anxiety and caffeine consumption in people with anxiety disorders. Psychiatry Res 1985;15:211-7.

72 DeFreitas B, Schwartz G. Effects of caffeine in chronic psychiatric patients. Am $\mathcal{J}$ Psychiatry 1979;136:1337-8.

73 Greden JF, Fontaine P, Lubetsky M, Chamberlin K. Anxiety and depression associated with caffeinism among psychiatric in-patients. Am f Psychiatry 1978;135:963-6.

74 Mikkelsen EJ. Caffeine and schizophrenia. I Clin Psychiatry 1978;39:732-6.

75 Roache JD, Griffiths RR. Interactions of diazepam and caffeine: behavioural and subjective dose effects in humans. Pharmacol Biochem Behav 1987;26:801-12.

$76 \mathrm{Cheeseman} \mathrm{HJ,} \mathrm{Neal} \mathrm{MJ.} \mathrm{Interaction} \mathrm{of} \mathrm{chlorpromazine} \mathrm{with} \mathrm{tea} \mathrm{and} \mathrm{coffee.} \mathrm{Brf} \mathrm{Clin} \mathrm{Pharmacol}$ 1981;12:165-9.

77 Shisslak CM, Beutler LE, Scheiber S, James JA, La Wall J, Crago M. Patterns of caffeine use and prescribed medications in psychiatric inpatients. Psychol Rep 1985;57:39-42.

78 Griffiths RR, Bigelow GE, Liebson IA, O'Keefe M, O'Leary D, Russ N. Human coffee drinking: manipulation of concentration and caffeine dose. $\mathcal{F}$ Exp Anal Behav 1986;45:133-48.

\section{Privatising water: implications for health}

It was the realisation by John Snow and others that a safe water supply depended on removing waste products that prompted public authorities throughout Britain to take over private water and sewerage companies. ${ }^{1}$ Now there are proposals to reverse the process. The white paper on privatising water supplies published in February 1986 proposed trials on metering water supplies to private dwellings. ${ }^{2}$ (The water supplies of industrial consumers are already metered.) If the trials are successful then water metering might be introduced for all private dwellings over several years. What might be the implications for health?

Half of the world's hospital beds are occupied by patients with waterborne diseases, and about 30000 children die every day from these diseases. An estimated three fifths of the world's population have inadequate supplies of drinking water, and one of the aims of the international drinking water 